\title{
Genetic services and testing in Brazil
}

\author{
Dafne Dain Gandelman Horovitz • \\ Victor Evangelista de Faria Ferraz • Sulamis Dain • \\ Antonia Paula Marques-de-Faria
}

Received: 26 December 2011 / Accepted: 8 April 2012 /Published online: 5 May 2012

(C) Springer-Verlag 2012

\section{Introduction}

The Federative Republic of Brazil is a country of continental dimensions, whose territory covers more than 8.5 million $\mathrm{km}^{2}$ and borders all the countries of South America except for Chile and Ecuador. After more than three centuries as a colony of Portugal, it became an independent monarchy in 1822 and a federal republic in 1889 . It was under a 20 -year long military dictatorship on the second half of last century, and today, after six presidential elections, the country has emerged as a consolidated democracy and as a political and economic leader in the region. The Brazilian economy also acquired a strong position in the global economy in recent years (IBGE 2010; United Nations 2010). It is defined as an upper middle-income country, but inequality remains significant, according to $\mathrm{Hu}-$ man Development Report (UNDP 2009).

For Special issue: GenTEE

D. D. G. Horovitz $(\bowtie)$

Centro de Genética Médica, Instituto Nacional de Saúde

da Mulher, da Criança e do Adolescente Fernandes Figueira,

Fundação Oswaldo Cruz,

Rio de Janeiro, Brazil

e-mail: dafne@iff.fiocruz.br

V. E. de Faria Ferraz

Departamento de Genética, Faculdade de Medicina de Ribeirão

Preto, Universidade de São Paulo,

Ribeirão Preto, São Paulo, Brazil

S. Dain

Instituto de Medicina Social,

Universidade do Estado do Rio de Janeiro,

Rio de Janeiro, Brazil

A. P. Marques-de-Faria

Departamento de Genética Médica, Faculdade de Ciências

Médicas, Universidade Estadual de Campinas (Unicamp),

Campinas, São Paulo, Brazil
Brazil is distinguished by an admirable national unity, based mainly in the Portuguese language, which is spoken in all regions, and by a magnificent biodiversity and natural resources. The agriculture is large and welldeveloped, while mining, manufacturing, and service sectors are having a significant growth. Notwithstanding, the country still faces economical, political, and social problems, whose paramount example is the highly unequal income distribution (IBGE 2010; United Nations 2010).

In the past decades, with health improvement of the population in general, due to more effective sanitation and better control of infectious and nutritional diseases, it can be stated that Brazil has been living an epidemiological transition. Taking such statement into consideration, birth defects and genetic diseases are increasingly assuming a more important role in morbidity and mortality, especially in large centers and reference hospitals (Horovitz et al. 2005).

This paper presents the background data on basic demographic statistics, health indicators and health expenditure, and information on the genetic services and genetic testing available in the country.

\section{Demography and health indicators}

In 2004, the Brazilian population surpassed 180 million and today is estimated in 190 million $(190,755,799$ in the 2010 census, IBGE 2011). In the last decades, the country underwent consistent changes on demography. The birth rate is around 3 million per year, and the population growth rate declined by an average of $1.9 \%$ annually during 1980-1990 decades, and in 2001, it was $1.4 \%$, reflecting the effect of birth control programs developed by the Brazilian government during the 1990s. Nevertheless, it has been estimated that the population size will have increased to 209.1 million 
by 2020 , according to the Human Development Report (UNDP 2009).

Eighty-four percent of the population are urbanized (Fig. 1a), reaching over $92 \%$ in some regions, such as the states of Rio de Janeiro and São Paulo, where there are some megalopolis as São Paulo, the main industrial and financial centre of the nation, surrounded by other large cities connected by modern highways; in contrast, there are regions with small hidden villages, some of them only reached by precarious trails, plane, or boat (IBGE 2011; United Nations 2010).

Concerning racial aspects, the country is a melting pot of different ethnical groups, although the majority is composed by bi and tri-hybrids mainly from the mixture of Caucasians and African descendants, in addition to Amerindians.
Taking into account the ethnical characteristics obtained during the 2000 census, using the options White, Black, "Pardo" (mixed color or race; mulatto or mestizo), Asiatic, and Native Brazilian Indian, the percentage of people that considered themselves as white are $54 \%$, while $39.9 \%$ are Pardos, $5.4 \%$ black, $0.5 \%$ Asiatic, and $0.2 \%$ Native Indians. The distribution is irregular, since in South region the white population reaches $84 \%$, while it is $62 \%$ in the Southeast. Inversely, there are most pardos or mixed color people in the population of North $(63.5 \%)$ and Northeast $(59.8 \%)$ regions (IBGE 2010; Marques-de-Faria et al. 2004).

It is a country predominantly young, with around $40 \%$ of the population under 19 years old, although the proportion of people over 35 years old has been increasing, reaching $34.5 \%$

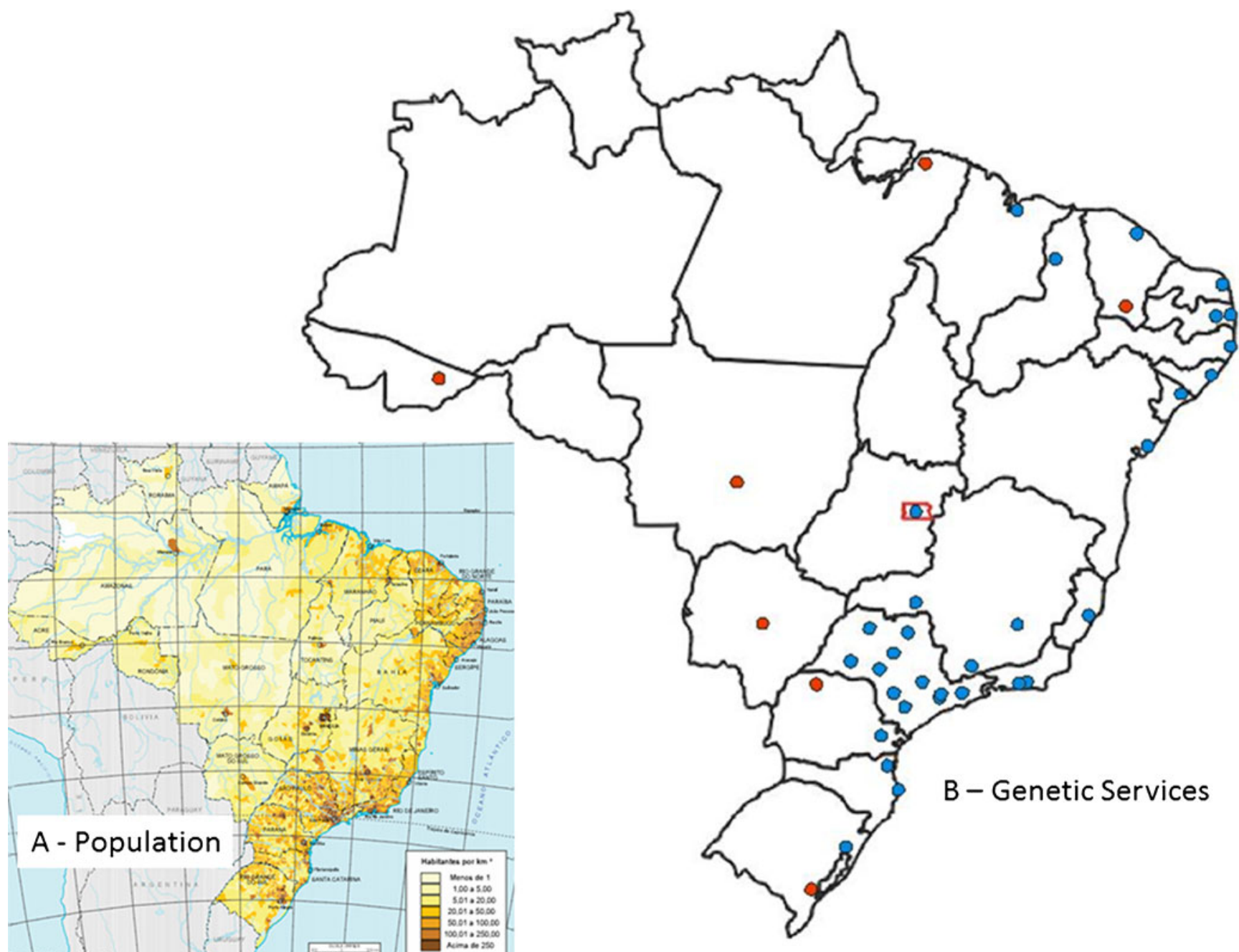

Fig. 1 a Brazil, population (2010)-population density (inhabitants per square kilometre). Colors range from under $1 / \mathrm{km}^{2}$ (lighter) to over 250/ $\mathrm{km}^{2}$ (brown). Source: Brazilian Institute of Geography and Statistics (IBGE), Directorate of Research, Coordination of Population and Social Indicators, population estimates according to 2010 Census (IBGE 2011). b Updated graphic representation of clinical genetic services in Brazil (2010), with aggregated information from the census by Horovitz (2003), outpatient information system and Brazilian
Society of Medical Genetics, plus updated information on new clinical genetic services (presentation of abstracts at meetings of the Brazilian Society of Medical Genetics and personal communications between the years 2003 and 2009). There is no reference to any type of care in the specialty in the states of Amazonas, Amapá, Roraima, Rondônia, and Tocantins. It is important to note that the service distribution in the country follows the population logic and that the less populated areas correspond to the Amazon forest or to swampy area 
in 2000 with a narrowing down in the base of the age group pyramid. The average life expectancy of Brazilians was estimated, in 2008, to be 73 years (WHO 2010; IBGE 2010). Another indicator, the healthy life expectancy has increased in the last decade, and in 2007, it was 66 years for women and 62 years for men - an average of 64 years (WHO 2010). The "adult mortality rate," defined as the probability of dying between the ages of 15 and 60 years was 158 per 1,000 in 2008, with women having a lower mortality rate (106) than men (210) (WHO 2010). The maternal mortality rate was estimated as 53 per 100,000 live births in 2008 (Brazil 2011a). Besides gradual aging of the population, other demographic modifications are the marked decline of fertility, the changes in the causes of death and the reduction of mortality level, as well as the improving literacy (IBGE 2010).

The annual population growth rate for 2005-2010 was given as $1 \%$ per annum by the Human Development Report (WHO 2010). That same report estimated the percentage of the Brazilian population made up of immigrants at $0,4 \%$ in 2005 (WHO 2010). Most (89 \%) of the births, between 2000 and 2007, were registered (WHO 2010), and the total fertility rate was 1.9 children per women in the period 20052010. This rate has been progressively decreasing for the past decades (WHO 2010). Approximately $9.93 \%$ of live births in 2007 were to women aged 35 and older (Brazil 2011a).

Between 2000 and 2008, $98 \%$ of pregnant women had at least one antenatal care visit, with $89 \%$ having at least four visits (WHO 2010; Brazil 2011a). Approximately $97 \%$ of births between 2000 and 2008 were attended by skilled health personnel (WHO 2010). The neonatal mortality rate was listed as 11 per 1,000 live births in 2008 (WHO 2010; Brazil 2011a), while the infant mortality rate was estimated to be 18-23 per 1,000 in 2007 (lower estimate data generated by WHO 2010; higher estimate data were generated by IBGE 2010). Male had a higher death rate of 20 per 1,000, while this rate was 16 per 1,000 for female. This is much lower than the 1990 mortality rate of 46-48 per 1,000 (51 per 1,000 for male and 40 per 1,000 for female); infant mortality rates have been progressively decreasing, especially after 1980 , when they were estimated as $72-82$ per 1,000 live births (IBGE 1999). The probability of dying by age 5 years (under-5 mortality rate) was 22 per 1,000 live births in 2008 (WHO 2010). This rate was again higher for male (24 per 1,000) than for female (19 per 1,000) (WHO 2010).

\section{Health expenditure and financing}

Brazil's gross national income per capita was US $\$ 8,070$ or International \$10,260 in 2008 (WHO 2010). This per capita income defines Brazil as an upper middle-income country. According to Human Development Report (UNDP 2009),
Brazilian Gini-index is 55, meaning a high level of inequality. Share of income or expenditure of the $10 \%$ poorer is $1.1 \%$, while the $10 \%$ richest represent $43 \%$.

A less unequal distribution is coming into existence in urban areas of Brazil. Data on income distribution among main metropolitan regions show that between 2002 and 2008 , the $10 \%$ poorest had an income increase of $22 \%$, while the $10 \%$ richest lagged behind, with an income increase of $4.9 \%$. The wage increase for the poorest has been 4.5 times more than that of the richest (primary data source from IBGE, Brazilian Institute of Statistics, elaborated by IPEA-Ministry of Planning).

Brazil's per capita government expenditure on health in 2000 was given as US\$107 and as US\$ 367 in 2009 (UNDP 2009). As a comparison, the total per capita expenditure on health in Brazil (government+private) was US\$267 in 2000 and US\$606 in 2007. Such figures reflect the (non)investment of the country in health. Brazil ranks 67 when comparing to other countries' investments in health, being the USA the highest per capita investment in health (and 10 times higher than Brazil); investment of the UK, ranking 19, is still more than four times higher. Brazil ranks tied to Cuba, and behind countries like Botswana, Montenegro, and the Russian Federation.

The per capita public expenditure on health in 2000 accounted for approximately $4.1 \%$ of the total government expenditure in that year; such percentage increased to $5.4 \%$ in 2007 (WHO 2010). As a percentage of the gross domestic product, total health expenditure (public and private) accounted for $7.2 \%$ in 2000 and for $8.4 \%$ in 2007 (WHO 2010). Private expenditure on health accounted for $58.4 \%$ of all health expenditure, while general government expenditure on health represented $41.6 \%$ of the total health expenditure in Brazil. Private prepaid health insurance plans comprised approximately $39.4 \%$ of private expenditure on health in Brazil (WHO 2010). Out-of-pocket expenses made up $58.8 \%$ of private expenditure on health (WHO 2010).

Data collected by WHO for 2000/2007 reveal an increase of total expenditure in health, in terms of percentage of GDP, as a percentage of General Government Expenditure in Health, and as percentage of Government Expenditure. As to private expenditure in health, which shows a slight increase in the aggregate figures, the weight of "out of pocket" expenditure should be pointed out, implying that neither private prepaid plans nor public health services cover population basic needs in term of health care. Data for "out of pocket" expenditure could be further divided into expenditure in medicines and other "out of pocket." Brazilian unofficial data for private expenditure on medicines point out that these expenditures represent $30 \%$ of private expenditure on health. A further increase in private prepaid plans as a percentage of private expenditure should be expected in the next years, as a result of increase in formal 
employment, which usually includes prepaid plans as part of indirect wages.

Additional remarks are necessary to clarify the data presented above. First of all, as Brazil is a federative state, the public health expenditure is distributed on three spheres of government (municipal, state, and federal) with constitutional local autonomy as to taxing and spending responsibilities. In 2006, federal expenditure in health corresponded to $46.7 \%$ of public total expenditure, while state and local government (municipalities) represented $26.2 \%$, and $27.18 \%$ of public expenditure in health. During 2000/ 2006, most increase in public health expenditure was due to increase in decentralized government expenditure, so that state and local government should be considered when analyzing trends in public health expenditure in Brazil.

In short, private and public funding are both essential to characterize Brazilian health expenditure. Although public health care is universal in Brazil, access varies among regions, towns and types of services. The public health system is funded on taxation and general social contributions and has been effective for the improvement and promotion of health, and as a guarantee to access to expensive medicines, but has not yet totally succeeded in the delivery of health services.

\section{The health system in Brazil}

The majority of the population is served by the public Unified Health System ("Sistema Único de Saúde" or SUS). It was created in conformity with the provisions of the 1988 Federal Constitution (Senado Federal 1988), to ensure universal and equal access for promoting, protecting, and recovering the health of all citizens fairly (Brazil 1990b). The system has a municipal basis, whose management is under state administrations, with the support of the Federal Ministry of Health. One fundamental step has been the development of a national health information database within the Ministry of Health, also known as DATASUS (Brazil 2011a). The SUS is one of the largest public health systems in the world. It includes most aspects of health care, from outpatient care to organ transplantation, and proposes to ensure full, universal and free of charge medical access for the entire Brazilian population. Besides offering appointments, medical exams, and hospitalizations, the SUS also promotes immunization campaigns, prevention, and health monitoring, such as food control and medicament registration.

According to the Federal Council of Medicine, $60 \%$ of 347,000 active physicians in Brazil are working on SUS, whose service extends to about 145 million people (CFM 2011a). The physician density in the country (general practitioners and specialists) is estimated around 18 physicians per 10,000 population. Such distribution, however, varies strikingly among different regions, being 27.9/10,000 in the southeast and only $11.4 / 10,000$ in the north (IBGE 2009). Nursing and midwifery personnel totaled 1,243,804 in 2007, with a general density of 65.7 per 10,000 .

In addition to the SUS, there is a thriving private health sector that serves $24 \%$ of the Brazilian population (46.6 million inhabitants), who have some sort of private health insurance coverage (private health care plans) (CFM 2011b). The quality of these services is variable, despite efforts by the Ministry of Health to regulate and improve them. In 2000, the National Agency of Supplementary Health [Agência Nacional de Saúde Suplementar (ANS)], a regulatory agency linked to the Ministry of Health, was created. The ANS has as main aim to promote the public interest in the supplementary health assistance, and it regulates the relationship among providers, government, and clients, by determining the minimum and mandatory coverage requirements for plans under contract, and also helps the development of health actions in the country (Brazil 2011b).

\section{Congenital and genetic disease burden}

A registry of genetic diseases is not available in Brazil. There are, however, some instruments that could provide excellent data if their importance was recognized by health authorities and if correctly used. The liveborn declaration (LD) - official document issued by hospitals, without which the children's parents cannot perform their civil registrationhad a new field introduced in 2000 (field number 34-Brazil 1999), partially modified in 2011 (fields 6 and 41-CEInfo 2011). Such LD allows congenital anomalies present at birth to be registered systematically. This information is not available in most countries; the data obtained may be an extremely valuable tool for monitoring and preventing birth defects in Brazil. Although the completion the fields regarding birth defects is not mandatory, the way they were elaborated, with a yes/no question for the presence of congenital malformation plus an open field provided for the description and classification of the all the observed defects according to ICD-10 could provide, if properly filled in, a fairly complete record of abnormalities.

By analyzing data available through the DATASUS related to births in Brazil in 2006, only $0.65 \%$ of liveborns were registered as having a congenital anomaly (Brazil 2009b), suggesting that such anomalies are being underreported. In 2008, last year available in the database, the figures remained very similar. When comparing data from the deaths caused by a congenital malformation with data from the liveborn registry, Cunha et al. (2002) demonstrated an underreporting of $60.7 \%$ of birth defects on birth certificates. Guerra, who also suggested an underreporting, showed unsatisfactory reliability in the coding of the 
recorded anomalies (Guerra et al. 2008a,b). This item's addition in the LD will only be relevant for programs regarding birth defects if it is effectively implemented; in addition, its importance has to be recognized, not only as epidemiological data, but rather as information that could help the planning of health care and actions to prevent birth defects.

The total birth prevalence of serious genetic congenital disorders in Brazil was estimated by the March of Dimes to be 57.2 per 1,000 live births (Christianson et al. 2006). When classifying by mode of inheritance, estimates of defects per 1,000 are the following: 7 for dominant single gene, 1.3 for X-linked, and 3.9 for recessive; and 3.6 for chromosomal and 36.9 for congenital malformations in general (Christianson et al. 2006).

There are no nationwide studies that estimate prevalence of specific single gene disorders. However, some data are available from the newborn screening program. The prevalence of sickle cell trait (Hb AS) is $4 \%(2-$ $8 \%$ ) among the general population and 6-10\% among afro-descendants. Estimated prevalence would be around 7,200,000 HbAS individuals, 25,000-30,000 with sickle cell disease and 3,500 new cases diagnosed each year (PNTN 2007). Cystic Fibrosis is only officially screened for only in three brazilian states; if the incidence considers exclusively births in such areas, it can be estimated as $1 / 10,000$. It is important to point out that the demographic composition in these states includes descendants from European immigration (Italy and Germany) and does not reflect Brazil as a whole. Regarding phenylketonuria, estimated incidence by the screening program is $1 / 23,000$ births, although incidence also varies among regions (PNTN 2007).

Some geographic clusters, listed in Table 1, were identified in Brazil by Estudo Colaborativo Latinoamericano de Malformações Congênitas (ECLAMC) [more information on ECLAMC see item 6.2), Instituto Nacional de Genética Medica Populacional (INAGEMP) (2011) or searching through mainstream literature. There are presently some other clusters under investigation.

The birth prevalence of neural tube defects as estimated by the March of Dimes is 6,390 new cases per year (Christianson et al. 2006). There are no official statistics available, and data from liveborn declarations would be a subregistry, as many children with this group of malformations are stillborn. Regarding later onset diseases, breast cancer is responsible for $28 \%$ among all cancers in women, and its estimated incidence is 51.7/100,000 (Brazil 2006). Specific statistics for hereditary breast cancer are not available, although this particular type of cancer is mentioned in the official cancer report by the ministry of Health, and estimated as $2,400-4,800$ new cases per year. The same source and also a recently created network for familial cancer estimate hereditary non-polypoid cancer in 1250 2500 new cases/year (Brazil 2006, 2009d).

Exposure to teratogens during pregnancy is an important public health issue in Brazil, where most drugs can be purchased "over the counter" and there is a widely spread culture of auto-medication. Misoprostol is known to induce vascular rupture defects and Möebius syndrome and is still widely used to induce illegal abortion, although not available in regular drugstores. The approved use of thalidomide, on a very limited basis and controlled by a federal law (Diario Oficial da União 2003), has also resulted in some fetal malformations. ${ }^{1}$ Recently, a resolution of the Ministry of Health-Agency of Sanitary Surveillance was published in order to improve the control in the use of thalidomide. It requires the reporting of adverse reactions and the inclusion of a photograph of a child with birth defects caused by thalidomide in the package, as well as establishes criteria for its return and disposal, and specifies the criminal liability for the improper use of thalidomide (Diário Oficial da União 2011). Fetal alcohol syndrome is possibly more frequent than imagined, and many pregnant women do not refrain from drinking. Awareness campaigns are very crucial to change this scenario. Consistent research has been conducted for the past years by the first and most important teratogen information service in the country, Sistema Nacional de Informação sobre Agentes Teratogênicos (SIATdescribed in item 6.2; Schüller-Faccini et al. 2001; Dal Pizzol et al. 2008; SIAT 2011).

By processing information from the Health Ministry's database on mortality, when removing and proportionately redistributing all the non-defined causes, perinatal causes were the leading cause of infant mortality in 1980, corresponding to $38 \%$ of deaths under 1 year; at the same year, congenital anomalies occupied the fifth position, representing $5 \%$ of the total. Such profile has been changing, and a proportional reduction in infectious, nutritional, and respiratory diseases can be noted. That way, congenital malformations became the second cause of deaths in children under age 1 year, representing $13 \%$ of the total in 2000. In 2006, congenital anomalies not only kept the second position but also became accountable for $16.3 \%$ of the deaths, exceeding the sum of the 3rd and 4th causes (infectious and respiratory, respectively; Fig. 2, Brazil 2010). Despite their magnitude, these statistics on birth defects and infant mortality did not determine government policies or initiatives for the prevention and management of such group of problems until 2004. On that year, the process for introducing medical genetics as a health policy of the

\footnotetext{
${ }^{1}$ In all but one of the recent cases, Thalidomide was not use by the person it was prescribed to, but by a family member, friend or neighbor!
} 
Table 1 Some examples of geographic clusters of single gene disorders in Brazil

\begin{tabular}{|c|c|c|c|c|}
\hline State & Region & $\begin{array}{l}\text { MIM } \\
\text { number }\end{array}$ & Disease & References \\
\hline Maranhão & Ilha dos Lençois & & Albinism, undefined type & $\begin{array}{l}\text { Freire-Maia and Cavalli } \\
1980\end{array}$ \\
\hline Bahia & Southern Bahia & 200700 & Achondrogenesis-Grebe & Quelce-Salgado 1964 \\
\hline Minas Gerais & Southeast MG & 200500 & Acheiropodia & Freire-Maia 1981 \\
\hline $\begin{array}{l}\text { Rio Grande do } \\
\text { Norte }\end{array}$ & Serrinha dos Pintos & 609541 & $\begin{array}{l}\text { Spastic Paraplegia, optic atrophy and } \\
\text { neuropathy (SPOAN) }\end{array}$ & $\begin{array}{l}\text { Macedo-Souza et al. (2005), } \\
\text { Macedo-Souza et al. (2009) }\end{array}$ \\
\hline $\begin{array}{l}\text { Rio Grande do } \\
\text { Norte }\end{array}$ & $\begin{array}{l}\text { Rio Grande do } \\
\text { Norte }\end{array}$ & & $\begin{array}{l}\text { Neural tube closure defects (NTD) and } \\
\text { hydrocephaly not related to NTD }\end{array}$ & INAGEMP 2011 \\
\hline Ceará & Tabuleiro do Norte & 230800 & Gaucher disease & INAGEMP 2011 \\
\hline \multirow[t]{2}{*}{ Bahia } & \multirow[t]{2}{*}{ Monte Santo } & $\begin{array}{l}253200 \\
261600\end{array}$ & \multirow[t]{2}{*}{$\begin{array}{l}\text { Mucopolysaccharidosis type VI, } \\
\text { phenylketonuria, } \\
\text { congenital hypothyroidism and cystic fibrosis }\end{array}$} & \multirow[t]{2}{*}{ INAGEMP 2011} \\
\hline & & 219700 & & \\
\hline
\end{tabular}

Ministry of Health began. Such topic will be detailed later in this text (item 6.6).

In certain tertiary care hospitals in Brazil, when looking on the three main diagnoses coded upon admission, birth defects/genetic disorders account for more than one third of total pediatric admissions (Horovitz 2003; Horovitz et al. 2005). Regarding congenital malformations in the Brazilian Ministry of Health's database, the 2008 hospital mortality rate in the pediatric age range (1-19 years) was 4.7 times greater when the primary diagnosis for admission was included in chapter XVII of ICD-10. An increment of the permanency and hospitalization cost for this group of diseases can also be noticed (Brazil 2009c).

\section{Availability of genetic services}

In Brazil, medical practice in genetics has had a recent onset when compared to other medical specialties. The Brazilian Society of Genetics [Sociedade Brasileira de Genética (SBG)]

\section{Brazil: Infant mortality by cause - 1980 to 2006}

(Source: DATASUS - Ministry of Health Database)

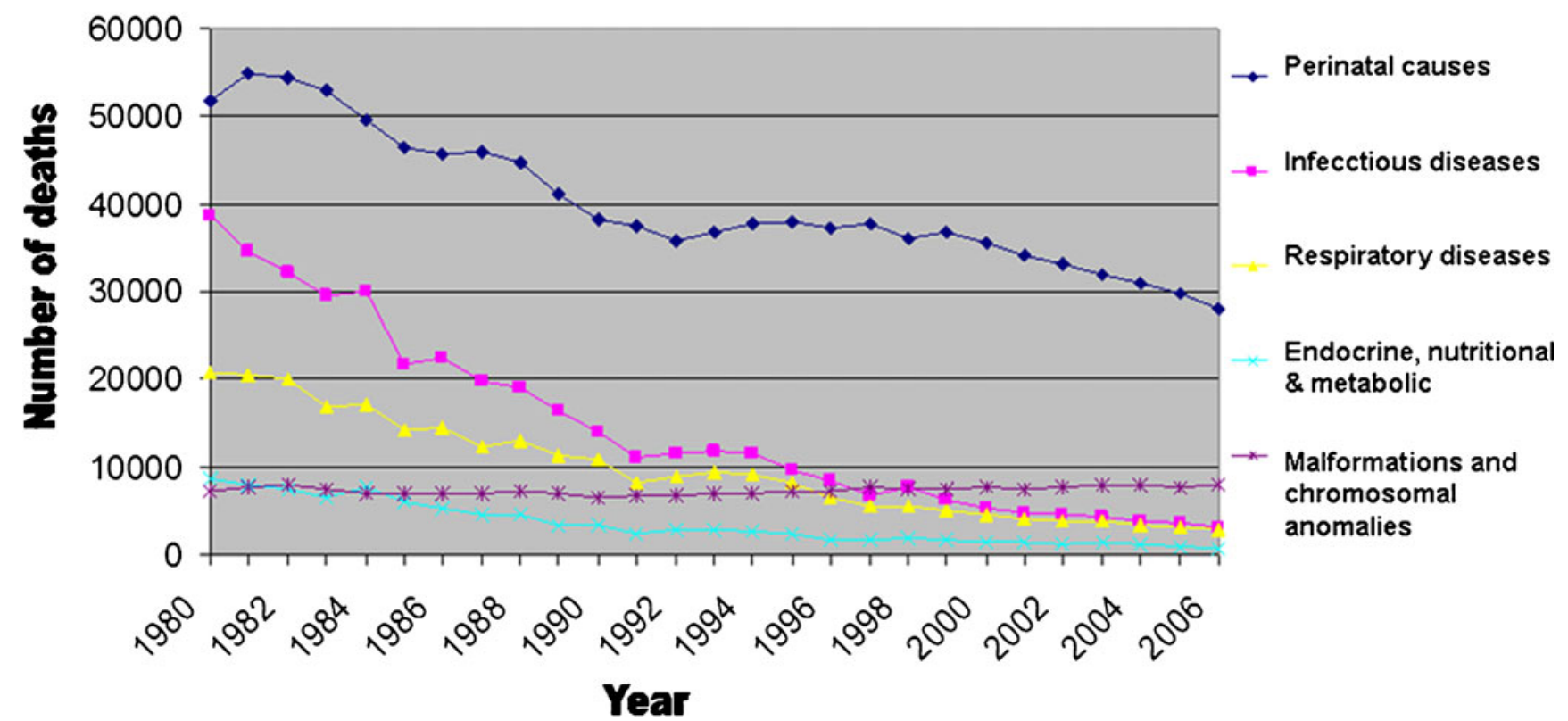

Fig. 2 Graphical representation of the evolution of proportional infant mortality due to the five major causes of death between 1980 and 2006 in Brazil. Original data were obtained from the Mortality Information System, accessed through DATASUS (http://www.datasus.gov.br) (Brazil 2010) 
was founded in 1955, and it brought together all people interested in issues related to genetics (Sociedade Brasileira de Genética 2009a). In the early 1980s, a group of physicians within the SBG began to discuss the need for a clinical society. That would be essential to turn clinical genetics into a medical specialty, since there already existed a fully recognized residency program at the time, which led to the creation of the Brazilian Society of Clinical Genetics (Sociedade Brasileira de Genética Clínica) in 1986 (Brunoni 1997). Later, it was renamed the Brazilian Society of Medical Genetics [Sociedade Brasileira de Genética Médica (SBGM)], which endows the board certification in Medical Genetics through an agreement with the Brazilian Medical Association and the Federal Council of Medicine, also regulating this medical specialty in the country.

Most centers and care services related to the clinical genetics field are concentrated in the Southeast and South, the most developed regions of the country. Such services are usually integrated to university and reference hospitals and are responsible for the medical care of thousands of individuals and families annually. Furthermore, they are considered as references at regional or national level. Some genetic services are also located in hospitals that specialize in specific conditions such as diseases and disorders of the locomotive system and craniofacial anomalies. Several of these institutions have laboratory infrastructure and are also capable of offering tests such as cytogenetic exams and several molecular biology techniques. However, the access to these services is limited. Although some of them are partly financed by the SUS, medical genetic services lack the organization as a network and are not fully and officially integrated to the national health system (Marques-de-Faria et al. 2004).

Despite the lack of a comprehensive health policy specifically focused on birth defects and that aimed to include genetics in the SUS, some government programs have emerged over the years. Many of these have originated from the pressure of groups of patients/families who fought for diagnosis or treatment, thus emphasizing the absence of the government in their formulation, although showing a timid presentation of the birth defects issue in the public policy agenda.

\section{Newborn screening}

Laws and regulations regarding screening of newborns for genetic/congenital disorders were introduced in several parts of the country since 1990 (Brazil 1990a; Brazil 1992), but the provision of screening varied by region and did not include facilities for diagnostic confirmation, clinical evaluation, treatment, family education, or genetic counseling. In response to these limitations, the National Newborn
Screening Program [Programa Nacional de Triagem Neonatal (PNTN)] was established by the Ministry of Health (Brazil 2001b). Its specific aims are to ensure equitable access to genetic screening for all Brazilian newborns, organize State screening networks, ensure therapy and followup for each disorder detected, reduce morbidity and mortality, provide guidelines to standardize regional services, and create and support a National Newborn Screening Database to collect epidemiological data. The following diseases are screened by the program: phenylketonuria (PKU), congenital hypothyroidism $(\mathrm{CH})$, sickle cell disease and other hemoglobinopathies (SC), and cystic fibrosis $(\mathrm{CF})^{2}$ (Brazil 2001b; Brazil 2001c; Marques-de-Faria 2006). Such recommendation followed a rationale of progressive implementation phases (phase I, PKU and $\mathrm{CH}$; phase II, $\mathrm{PKU}, \mathrm{CH}$ and $\mathrm{SC}$; phase III, $\mathrm{PKU}, \mathrm{CH}, \mathrm{SC}$, and $\mathrm{CF}$ ), taking into account existing inequalities in health care structure. The reference services for newborn screening should ensure not only the screening process but also diagnostic confirmation and appropriate monitoring and treatment of screened patients. By 2007, there were referenced services registered by PNTN in all states of Brazil, which provided the coverage of $80 \%$ of newborns (PNTN 2007). The programs' experiences show important data, such as the possibility of good quality coverage, agility in the process, and also the integration capability between the primary health care and reference centers. The PNTN is run by municipal and state health offices; the global supervision is entrusted to the technical advisory group, established and coordinated by the Health Care Department of the Ministy of Health ${ }^{3}$ (Brazil 2001c; Marques-de-Faria 2006).

\section{Treatment programs}

Treatments for some genetic diseases are being undertaken by the Ministry of Health and regulated by ministerial decrees. The process is complex, especially due to issues like the very high cost of some treatments, often involving legal actions or strong lobbying by families, based in the Federal Constitution, whereby everyone has the right to

\footnotetext{
2 The movement that began in civil society organizations (families with cystic fibrosis) was essential for the creation of the National Newborn Screening Program in Brazil. For this reason, despite existing doubts regarding the validity of screening for that disease on a public health level in Brazil, and at the expense of not investigating for other possibly more frequent diseases, or for diseases for which screening or treatment could be more effective, it was incorporated into the group of diseases to be investigated.

${ }^{3}$ The "Secretaria de Assistência a Saúde-SAS", referenced in this text as the Health Care Department, is a branch of the Brazilian Ministry of Health that plans and coordinates integrated health care actions.
} 
health and to health care, which should be provided by the State (Senado Federal 1988). Some of such treatments are described below.

Osteogenesis imperfecta In December 2001, an ordinance was published instituting the treatment of osteogenesis imperfecta (OI) within the Brazilian Health System with bisphosphonates, which helps to decrease the bone reabsorption, to gain bone mass, to reduce the number of fractures and to improve the patient's quality of life (Brazil 2001e). It is presently estimated that there are more than 700 OI patients under follow-up through this specific program in Brazil (Santos, personal communication, 2009).

Gaucher disease It was the first metabolic disease to be treated by enzyme replacement therapy, introduced in clinical practice in the 1990s. The Brazilian Association of Gaucher Disease, founded in 1994, had the first judicial injunction abided to purchase the medicine from 1995. Nowadays, the medication is directly financed by the Ministry of Health. In 2002, an official protocol was established, which set up state reference centers for evaluation, treatment, and monitoring of patients (Brazil 2002a). Currently, the recombinant enzyme used to treat Gaucher disease is the most expensive drug in the country's extraordinary dispensation medicaments program. Moreover, the creation of the treatment program allowed an optimal access to therapy for more patients, not only due to the decrease in the individual medication's cost (direct negotiation between the Ministry of Health and the pharmaceutical industry) but also due to more organized treatment dynamics, as opposed to treatment on an individual basis.

Cystic fibrosis The estimated incidence is around 1:10,000, but varies greatly among regions (its highest prevalence is in the south due to European immigration). It is advocated that an early diagnosis and the institution of preventive measures would improve the quality of life and patients' survival. Besides the inclusion of this disease in the national newborn screening program, an ordinance was published in 2001, which established a clinical protocol and guidelines for treatment, which also includes the supply of pancreatic enzymes for the disease (Brazil 2001d).

Some aspects regarding the adoption of therapeutic programs for genetic diseases by the SUS should be highlighted. Treatments for other metabolic diseases are presently available (such as lysosomal diseases-Fabry, Mucopolysaccharidosis types I, II, and VI and Pompe disease, for which there are already enzyme replacement therapies; aminoacidopathies benefited by special dietary treatment, among others) or are in final development stages. Treatment requests made by families and patient associations, based on the Federal Constitution, are almost always abided by courts. It is essential that new programs follow well-established protocols such as those currently available. Along with the treatment programs, strategies for the prevention of new cases should be outlined, and the role of medical genetics and genetic counseling is essential in this process. Genetic counseling is one of the few possibilities of stabilizing the treatments' rising costs (WHO 2000).

The genetics network available in Brazil

The most recent census work related to the mapping of medical genetics services in Brazil was completed in 2003 (Horovitz 2003). This work aimed to locate public medical genetic services available to the Brazilian population, including those related to laboratories, integrated or not to clinical centers and to medical schools. At the time, clinical care in the specialty was offered in 48 institutions, and 33 out of those were somehow integrated to a genetic laboratory. More recent data ${ }^{4}$ show that new genetic services are being implemented in states previously devoid of such kind of assistance. Nevertheless, the following Brazilian states still lack specialized care in genetics: Amazonas, Amapa, Roraima, Rondônia, and Tocantins (Fig. 1b).

The greater lack of services is in the North Region. Regarding the Northeast region, services are mainly clinical, without local laboratory support in some of the states; on the other hand, the number of yearly medical consultations is quite impressive in some of those services. The majority of medical genetics services in Brazil are located in the Southeast region or in state capitals in general, being the state of São Paulo a noticeable exception, with services being provided throughout the state. According to data provided by services (Horovitz 2003), approximately 56,000 outpatient consultations in clinical genetics are estimated annually in the country (including counseling of couples and prenatal genetic counseling). From this amount, fewer than 16,000 cases represent first-visit patients, and it is noteworthy that out of the total demand, more than half of them were performed in only nine services.

If considered that all newborns with birth defects need a genetic evaluation, with a minimally estimated incidence of malformations ( $2 \%$ of total births), at least 60,000 first-visit consultations per year would be necessary in the country. ${ }^{5}$ The estimate has even higher deficit if the broadest definition of birth defects is considered, including problems not necessarily detected at birth and also developmental disorders (in that case, $5 \%$ of total births would represent 150,000 new cases

\footnotetext{
${ }^{4}$ Such data were obtained by personal communications, annual conferences' proceedings of the Brazilian Society of Medical Genetics, and also from the society's member listing.

${ }^{5}$ These figures consider an average of 3 million births per year in Brazil.
} 
per year in Brazil). It is also worth remembering that many medical consultations regarding birth defects are related to problems during pregnancy. Genetic counseling is also recommended to parents of stillborn malformed babies, and such statistics were not even included in the estimates above. By analyzing these data, the number of appointments offered is far below the actual need.

\section{Medical genetics laboratories and laboratory network}

The availability of diagnostic exams for genetic diseases follows similar distribution logic as the medical genetic services in Brazil, being uneven, with higher concentration in the South-Center region and with a variable complexity range (Marques-de-Faria et al. 2004; Horovitz 2003). Presently, there is no logical referenced flow for diagnostic tests, although clinical services around the country send and receive samples based on informal agreements between them.

A closer look at the latest research on genetic services in Brazil (Horovitz 2003), updated with information not yet published, ${ }^{6}$ shows that diagnostic genetic tests were available in 47 out of 66 genetic services linked to the SUS (71\%). Among these, $83 \%$ offered conventional cytogenetics, $55 \%$ high resolution cytogenetics, $32 \%$ fluorescent in situ hybridization, $36 \%$ tests for inborn errors of metabolism, and $32 \%$ prenatal diagnosis. Around $50 \%$ also performed investigation using molecular biology techniques for several groups of diseases, including mental retardation, dysmorphic syndromes, cancer predisposition, infertility and metabolic diseases, among others. Until today, there is no structured or published data on the number of genetic tests available in Brazil. Obviously, it is understood that this set of laboratories is insufficient to meet the needs of new annual cases, and also of the raising demand of cases that still lack diagnosis in the country. Only for new Down syndrome patients, over 4,000 cytogenetic tests would be needed annually; if considering that about $50 \%$ of children with birth defects would also need this exam, we would have an annual need of 45,000 cytogenetic tests (assuming a rate of $3 \%$ birth defects). Such figures do not consider infertility and other genetic disorders. Testing in genetics can be quite complex and expensive, which partly explains the need to organize a laboratory network to support diagnosis. This network is informally organized in Brazil by health professionals. Unpublished data show that the most

\footnotetext{
${ }^{6}$ Information updates on services, including those non existing or not computed in 2003 (time of the survey); the information was obtained through personal communications or through published data in the annals of the Brazilian Society of Medical Genetics meetings between 2004 and 2009.
}

popular e-mail topic in a medical genetics web-based discussion list (about $21 \%$ ) is information requests about exams for genetic disorders (Genetica Clinica 2009)

\section{Medical genetics and private health care in Brazil}

Genetic services in private medical offices and clinics are available in some of the main cities in Brazil, although following the same rationale of the general distribution of the public genetic services. The main differential between private care and consultations in public hospitals is the speed of the investigation and access to complementary exams, both for general and specific genetic investigation. Due to media coverage and publicity regarding genetics, there is more pressure on the private sector for laboratory diagnosis of genetic diseases. Several laboratory procedures (cytogenetics, biochemical and molecular techniques including in situ hybridization and prenatal diagnostic tests) have mandatory coverage by insurance; some tests have to be made available according to specific guidelines. A large number of clinical laboratories now offer testing by molecular biology techniques, not only for genetic diseases but also for infections; in addition, there are several laboratories exclusively specialized in the diagnosis of genetic diseases. The distribution of these laboratories also follows the concentration pattern in the Center-South region, although genetic testing is offered throughout the country by local laboratories, which often function as blood drawing centers; samples will be sent out to reference laboratories within the Center-South. Testing such as preimplantation genetic diagnosis, prenatal diagnosis, expanded newborn screening, genetic screening based upon an index patient, predictive testing, and pharmacogenetics are available in the private sector, although not always covered by insurance. Availability of more specialized testing within the public health system is possible, but much more limited. No population based genetic screening is routinely performed or recommended in the country.

Only an insignificant minority of patients from the upper class usually pays for medical care out of pocket or travel abroad for care; when they do, it is usually for a second opinion or very specific treatment. Regarding patient samples, it is not very usual to send them abroad; some are, however, as part of collaborative very specific researches. Some samples for newly available or rare disease investigation are sent abroad on an individual basis by commercial laboratories, such as array-CGH, molecular diagnoses for very rare diseases and cells for pre-implantation diagnosis. The country does not regularly purchase testing from abroad; on the contrary, Brazil provides genetic testing for some countries in South America, Africa, and the Middle East, usually done as research projects or as clinical testing demanded by individuals. 


\section{Pregnancy termination}

In Brazil, abortion is only considered legal in cases of pregnancy resulting from rape or if the continuation of the pregnancy is considered life threatening for the mother (Criminal Code of 1940). 40 services in 21 states perform such legal abortions; these are performed quite rarely, with a total of 2,508 in the year 1998 and 3,241 in the year 2008 (Brazil 2008).

Despite being mostly illegal, abortion for unwanted pregnancy is widely performed for those who can afford it. A recent study, concluded in 2008, estimated 1,054,242 induced abortions in 2005; the induced abortion tax would be 2.07 per 100 women between ages 15-49 (Brazil 2008; Diniz and Medeiros 2010).

Such figures would include termination for fetal malformation, despite these being an insignificant minority. For the past two decades, however, some women have been able to terminate pregnancies in cases of fetal malformation with special lawsuits. $^{7}$

Special care facilities, rehabilitation services, education, and social services for people with disabilities

Special care facilities available for affected children, such as medical care, social services, rehabilitation, and education are quite limited. They are usually overcrowded, the working staff is underpaid, and most are public or philanthropic. It deserves mention that a comprehensive care through SUS should be assured for children and adolescents with disabilities, with warranty of universal and equal access to actions and services for promotion, protection, and restoration of health. There are private services, but these are too expensive and very few can afford. Non-medical care such as physical therapy, speech therapy, occupational therapy, and others are not covered by most private medical insurance companies.

Regarding continuing medical care, primary care physicians and general practitioners usually do not want (or claim not to know how) to care for patients with disabilities. Genetic services are overcrowded, and when patients with genetic diseases keep being followed up clinically on a regular basis, access to genetic services by others in need becomes even more difficult. About these issues, it deserves mention that a comprehensive care through the SUS should be assured for children and adolescents with disabilities, with warranty of universal and equal access to actions and services for promotion, protection, and restoration of health, by the Child and Adolescent Statute (Statute of the Child and Adolescents 1990).

Regarding education for children with disabilities, it is surprisingly more available and accessible within the public

\footnotetext{
${ }^{7}$ From the 1990 s, court orders that allow pregnancy terminations in cases of anencephaly and severe fetal malformations (mostly incompatible with life) have been obtained, although discussions on the decriminalization of abortion still have lots to evolve.
}

sector, as opposed to private education. In Brazil, as a general rule, the best schools (basic education up to high school) are private, with few exceptions; such schools claim not to be "prepared" for education of children with disabilities.

There are many social benefits from the government especially provided for people with disabilities, such as free transportation, an extra salary, and others. The extra salary, called the Benefit of Continuous Social Welfare, is a social assistance paid by the federal government and guaranteed by law (Brazil 2011c), for the elderly and disabled. Nevertheless, for receiving the extra income, regarded by some families as the "retirement" salary for the disabled, the family must be extremely poor, as it is only made available if the per capita income in the family lies below $25 \%$ of the minimum wage in the country. In the event of multiple disabled per family, the same rule applies, meaning that a family would only be entitled to a second benefit if there was practically no income and at least five or six people in the same household.

\section{Access to genetic services}

Only around $25-30 \%$ of the estimated need in genetics is being cared by specialists in the field (see item 4.3). The barriers are various, and excessive waiting time due to insufficient services/professionals in the area is just one of them. Diagnosis is often delayed, and many needy patients are not even referred, due to complete lack of knowledge regarding the specialty of clinical genetics by many physicians and health workers. Surprisingly, non-referral also occurs within the private sector. Geographical barriers also exist, as most specialists are concentrated in the South-Southeast regions.

After the patient/family has had access, it is also quite usual not being able to offer certain exams that would be important for confirming the diagnosis and establishing follow-up recommendations, such as FISH or methylation studies in Prader-Willi and Angelman syndromes, or a molecular diagnosis for Fragile-X syndrome. In the private sector, these exams have been accessible by the new rules of health insurance since 2008. Some tests for rarer disorders that are not available in the country may be made accessible on a one-on-one basis, but generally only for those who can afford out of pocket payment.

Prenatal and preimplantation diagnoses are more available in the private sector, due not only to cost but also to legal constraints (see item 4.6). The society is quite hypocritical on that matter, for many who can afford usually opt for prenatal diagnosis and illegal termination. The registered number of malformed newborns in private higher class hospitals is practically non-existent, certainly due to more information plus the access to illegal and safe abortion. Prenatal invasive diagnosis is only available in less than a dozen public genetic services around the country. 
As historically the genetic services started growing in research settings and universities, the specialty was viewed as non-clinical, despite the progressive translation of research to the clinic. Many clinical genetics departments in Brazil are still within basic research departments, such as morphology of basic genetics. With the creation of the SUS, clinical genetics has not received the status of a medical specialty, and reimbursements both for clinical and laboratory exams have become scarce. Lack of funding and non recognition in the SUS also results in very few working spots opened yearly for new specialists. Some years ago the Ministry of Health began to realize that medical genetics should be integrated in the system just as other medical specialties; details of such process will be described in item 6.6 .

\section{State of genetic services}

Training of human resources in medical genetics

Perhaps one of the most critical points for the success of a national policy based on comprehensive care in Medical Genetics is human resources. The evaluation and care of families with needs in this area requires training on topics poorly covered during higher education in medicine and in the health care field, such as non-directive genetic counseling, dysmorphology, and syndromology, and also basic knowledge of genetic testing. Moreover, the training of specialists in medical genetics still has a low numerical impact. Adding to this the fact that specialists tend to settle within the major services in the Centre-South region of the country, it turns out that most Brazilian states have very few or no trained professionals in clinical genetics. Thus, professional training demanded by the health needs in this field could be divided into: genetics training within the undergraduate health courses and specialist postgraduate training.

\section{Genetics training in medicine}

In Brazil, Genetics is part of the curricula in several healthrelated graduate schools, either as a structured discipline or among one of the major themes such as cell biology. It is classically taught within the basic disciplines of the courses with little, if any, integration with practice. Few medical school curricula include practical training in genetics. A survey conducted by Porciuncula in 2004 shows great heterogeneity of content in medical schools. There is a strong presence of genetics within the so-called basic cycle, and also a growing approximation with the professional practice, especially with the inclusion of specific disciplines of medical genetics in the clinical cycle (Porciuncula 2004). When analyzing his data on the surveyed medical schools in comparison to national and international literature, the author proposes that an array of abilities, skills, and attitudes towards medical genetics be built, adapted to Brazilian needs. The education in medical genetics in Brazil still suffers from the absence of such a document, for the strengthening of the contents of medical genetics in health care teaching, strongly epidemiologically anchored, is a fundamental part of the effort to better deal with these problems in Brazil today. Considering this background, the genetics content in almost all medical schools does not cover even the needs of a general medical education. Therefore, most physicians do not recognize the genetic basis of diseases with which they are dealing and/or do not know how to refer to genetic services and/or do not give the deserved importance to the process of genetic counseling.

\section{Postgraduate training: the stricto sensu postgraduate programs}

The stricto sensu postgraduate programs in Genetics in Brazil have been collaborating with the training of professionals for teaching and research in Medical Genetics. Although the primary purpose is to train professionals for universities and research centers, a reasonable proportion eventually ends up being trained in specific areas of medical genetics, particularly regarding laboratory investigation in cytogenetics, biochemistry, and molecular biology.

The traditional academic training in genetics in Brazil leads to a diverse panel of scientific research in Medical Genetics. A very brief analysis performed by Brunoni (2002), when assessing major themes of papers presented at the Brazilian national meetings of genetics and medical genetics, also points to a large concentration in a few research centers, mainly within the Center-South of the country. The nonmedical professionals whose undergraduate or postgraduate training enables them to perform within medical genetics, or even those who enter the area by the practice, may obtain qualification through their associations, although few opt to do so. The Brazilian Society of Genetics (SBG) has been conducting certifications in Human Cytogenetics and in $\mathrm{Hu}-$ man Molecular Genetics since 1999, through an agreement with the Federal Councils of Biology, Biomedicine, and Pharmacy. Until 2007, around a dozen professionals had obtained such certification (Sociedade Brasileira de Genetica 2009b). Clinical geneticists can obtain specific certification in Medical Cytogenetics, Medical Molecular Genetics, and Medical Biochemistry through the Brazilian Society of Medical Genetics.

\section{Postgraduate training: medical specialization in medical genetics}

The first medical residency program in Medical Genetics in Brazil, recognized by the Ministry of Education, was installed in the Hospital of the Medical School of Ribeirão 
Preto, University of São Paulo in 1977. In 1983, Medical Genetics was recognized as a medical specialty by the Federal Council of Medicine. Since then, several new residency programs were created, totaling 11 programs, and vacancies for 23 new physician trainees yearly. The program approved by the National Medical Residency Committee is of direct access (after the end of undergraduate medical training) and lasts 3 years (Comissão Nacional de Residência Médica 2006). Of the 11 programs, 8 are in the Southeast (4 in Sao Paulo, 3 in Rio de Janeiro, and 1 in Minas Gerais), two in the South (Rio Grande do Sul) and 1 in Brasília-Federal District (Secretaria de Educação Superior 2009). This distribution follows the already described logic of the high complexity services, also heavily concentrated in these regions.

Expertise in a medical specialty in Brazil is not based solely on the titles coming from medical residencies and recognized by the Ministry of Education. Another form of professional recognition comes from board certification, awarded by the societies of medical specialties and recognized by the Brazilian Medical Association and the Federal Council of Medicine. Board certifications in Medical Genetics are held annually since 1993 by SBGM and involve a theoretical test, analysis of curriculum and interviews. This type of certification, often also pursued by those who were already certified by the medical residency programs, allows physicians with stricto sensu postgraduate training and those with practical training for several years in medical genetic services to be recognized as specialists. Data collected in 2010 by the Brazilian Medical Association and the National Commission of Medical Residency shows that around 200 physicians have been awarded board certification in Medical Genetics since 1981 in Brazil.

\section{Genetic counseling}

Despite the involvement of many professionals in care regarding genetics, clinical evaluation and genetic counseling are delivered predominantly by physicians, with few exceptions (nurses counseling patients with inherited cancer in some reference centers; genetic information regarding sickle cell trait after newborn screening given in primary care settings, for instance). The profession of genetic counselor is not recognized in Brazil.

\section{Training of human resources-conclusion}

Professional training for health professionals in medical genetics is present in Brazil, although highly concentrated in central-south regions of the country. This would partly allow the training of non-geneticist human resources for the SUS network, in a continuing education strategy, enabling them to identify, appropriately manage the most common problems and to recognize the need to refer to specialized services. A direct action on the undergraduate courses in the health-related areas, however, is long overdue. The medical schools, as well as other health-related courses, have been heterogeneously adapting to these new requirements, demanded by the changing epidemiological profile of Brazil. As for skilled professionals, they are few; most remain working in the medical genetic services highly concentrated in the central-south area of the country.

Workload, integration, and networking

The estimated workload of genetic consultations per health care professional/per year is very hard to estimate, as a special code for consultations in genetics is no longer available in the DATASUS. But if we combine data from Horovitz (2003), in which the number of physicians per service was not computed, and the number of certified specialists in the country, considering that there would still be around 60,000 outpatient consultations per year, the estimated workload would be 300 outpatient consultations per specialist. It must be reminded that many services have inpatient consultations in nurseries and intensive care units and that some are also dealing with treatment of genetic diseases. Some of the largest services have around 1,500 consultations per doctor per year. In addition, due to the fact that medical genetics is not recognized as a medical specialty in SUS, many physicians work in other areas of medicine as well, such as pediatrics, endocrinology, neurology, and others, being a "part-time geneticist".

Issues regarding the number, location, and regional distribution of medical genetic departments/medical genetic units in the country, including service networking activities, and coordination with other health services have been addressed in Part 4.3. It must be pointed out that networking is a very important characteristic of medical genetics in Brazil, which may somehow compensate the lack of laboratory services in some regions. Samples are sent to reference centers from all over Brazil, not only linked to specific research projects but also in order to help those devoid of resources. This topic has been a differential over the years and may be very important in helping to build an integrated network in clinical genetics for the country.

There are several genetic-disease-related networks operating in Brazil, and they all share common features: usually the coordination is based in a tertiary hospital or research facility; specialists who deal with the specific diagnoses throughout the country are encouraged to participate, are financed by research-financing agencies and they help with diagnosis at large - providing clinical expertise and also diagnostic tests. Such networks, which informally become the main epidemiological references for the country, are described below. 
ECLAMC-registry of malformations in newborns and birth research in birth defects

The Estudio Colaborativo Latino Americano de Malformaciones Congenitas (ECLAMC; Collaborative Study on Birth Defects) can be defined as a continental network of persons interested in research and prevention of birth defects. It has always functioned as an independent research project, with operations beginning in Argentina, and gradually expanded to all countries of South America, as well as Costa Rica and the Dominican Republic. ECLAMC has been a founder member of the International Clearinghouse for Birth Defects Monitoring Systems; since 1994, a WHO Collaborating Center for the Prevention of Congenital Malformations, and since 2000, a collaborating member of the NIH Global Netwok for Women's and Children's Health Research. The program was designed for clinical and epidemiological investigation of risk factors in the etiology of congenital anomalies in Latin-American hospitals, using a case-control methodological approach. It is a voluntary agreement among professionals, lacking institutional base or designated budgets, and has been usually funded by research-funding agencies rather than public health ministries. In the network hospitals, around 200,000 babies are examined each year. ECLAMC systematically observes the fluctuations in the frequencies of different malformations as a system of epidemic surveillance, and, in the case of an alarm for a probable epidemic of a given malformation, it acts to identify its cause. ECLAMC is presently the most important program of birth defects monitoring in Brazil. Since 2000, with the introduction of the new model of the newborn declaration by the Ministry of Health, comprising a field for registration of birth defects, the ECLAMC network has also actively worked for its correct use and implementation (Castilla et al. 1996; Castilla and Orioli 2004; Horovitz 2003)

\section{INAGEMP—National Institute for Population Medical Genetics}

Recently, the Instituto Nacional de Genética Médica Populacional or "National Institute for Population Medical Genetics (INAGEMP)" was created in order to generate theoretical and conceptual bases in the field of population genetics and to apply this knowledge in the research of Brazilian populations with high frequencies of genetic and/ or congenital diseases (INAGEMP 2011). One initiative is a national census of Brazilian subpopulations with high prevalence of mono- or oligogenic diseases or characteristics or exposed to genetic risk factors (e.g., inbreeding), environmental (e.g., mercury), or unknown, on the occurrence of any physical or mental developmental disorder. Complemented by the creation of a virtual library specializing in population and isolated clusters of diseases called "genetic," INAGEMP represents the first step towards a specialized center for research and standardization of medical care for genetic conditions, offering technical and methodological support services for geneticists and affected communities (INAGEMP 2011).

\section{SIAT-Teratogen Information System}

In 1990 SIAT (Sistema Nacional de Informações sobre Agentes Teratogenicos-Teratogen Information System) was implanted in the in the Department of Medical Genetics, in Hospital de Clínicas de Porto Alegre of the Federal University of Rio Grande do Sul, having been the first of its kind to operate in Latin America. Its main objectives are to prevent the birth defects in humans resulting from environmental exposures and to deepen the knowledge of teratogenesis in humans (SIAT 2011). Such service, aimed for pregnant women and doctors from various specialties, operates through a free phone line, fax, or internet, providing information on exposures of pregnant women to chemical, physical, and organic agents. They also host a website with good basic information on more frequent exposures (http:// gravidez-segura.org/). All the service provided is free of charge. The service is also active in researching teratogenicity of environmental agents through monitoring and observation of the end of all pregnancies undergoing consultations.

\section{Projeto Crânio-Face Brasil (Cranio-Face Brazil Project)}

Projeto Crânio-Face Brasil (Cranio-Face Brazil Project started in 2002 to verify the number, distribution and type of care offered to patients with craniofacial anomalies in the country, including clinical genetics and genetic counseling. It also includes the development of continuous education programs for health care professionals in the notification of those defects, as well as phonoaudiologic assistance to patients with cleft lip or palate (Monlleo and Gil-da-Silva-Lopes 2006).

Serviço de Informação Sobre Erros Metabólicos-SIEM (Information Service for Inborn Errors of Metabolism)/ Rede-EIM-Brazil (IEM-Brazil-Network)/Rede-MPS-Brazil (MPS-Brazil-Network)

SIEM (www.siem.ufrgs.br) was implemented in 2001 in Hospital de Clinicas de Porto Alegre, the national reference center for inborn errors of metabolism (IEM). It aims to support physicians and health professionals in situations involving clinical suspicion of IEM. It also operates by a free phone line or internet communication and supplies guidelines on clinical diagnosis, management, and laboratory investigation recommended for each case. SIEM is 
complemented by another network, the Rede-EIM-Brazil (IEM-Brazil-Network: www.redeeimbrasil.ufrgs.br), also based in Porto Alegre, which has several associated reference centers around the country. It supplies specialized laboratory investigation for IEM. The Rede-MPS-Brazil (MPS-Brazil-Network: www6.ufrgs.br/redempsbrasil) is specific for the mucopolysaccharidoses, providing not only diagnostic expertise, but also conducting scientific research and meetings for the elaboration of clinical consensuses. The creation of similar networks would be an important step not only for Brazil but for Latin America (Giugliani 2010). Besides providing information and specialized exams, that otherwise would not be available through the public health system, the networks end up being able to concentrate information and, consequently, epidemiological data on several rare diseases (Giugliani 2010).

\section{The National Familial Cancer Network}

The National Familial Cancer Network is supported by a research grant that encourages the formulation, implementation, and evaluation of public actions aimed for the National Policy for Clinical Genetics in SUS. It is a multicentric network formed by medical genetic centers at strategic points in all the geographical regions of the country, coordinated by the Division of Genetics at the National Cancer Institute; the network is qualified for diagnosis, genetic counseling, and laboratory support for mutation detection in different hereditary cancer syndromes. Four sub-networks are operating in the project: Genetic Counseling, Laboratory, Clinical Research/ Hereditary Tumor Bank, and Epidemiology. Specific diagnoses that are being followed are hereditary breast and ovarian cancer syndrome, hereditary non-polypoid colorectal cancer, familial adenomatous polyposis, retinoblastoma, syndrome of breast and hereditary colorectal cancer, Li-Fraumeni syndrome, von Hippel-Lindau, multiple endocrine neoplasia type 2, familial melanoma, and Fanconi anemia. The National Familial Cancer Network Operating Manual was published in 2009, with specific guidelines for diagnosis and management of all these syndromes (Brasil 2009d).

Despite the existence of this network, a significant number of individuals at high-risk for hereditary cancer in public Brazilian cancer services may not have access to the benefits of genetic counseling in these centers. Contributing factors may include insufficient training of health care professionals, insufficient information of cancer patients, difficult access to genetic testing, and/or resistance in seeking such services. The identification and understanding of these barriers is essential to develop specific strategies to effectively achieve cancer risk reduction in Brazil and in other countries where clinical cancer genetics is not yet fully established.
Genetic testing

As shown in Part 4, among the public clinical genetic services, there are 47 laboratories where some type of genetic testing is available; most perform basic cytogenetics. Some public genetic services buy tests in private laboratories on a limited basis.

According to the Brazilian Institute of Geography and Statistics (IBGE 2009), there are 12,850 clinical laboratories in Brazil (3,140 public, 9,740 private, and 4,025 public/ private). There is no information on how many offer genetic tests. Regarding private laboratories, on an internet search among those who are members of the clinical pathology and/or laboratory association, there are around 50 laboratories who offer testing in clinical genetics. Several have branches in its home state and/or region and even in other parts of the country, concentrating the most complex tests in a single laboratory. Among those offering genetic testing, around $25 \%$ are exclusively genetic laboratories, specialized in molecular genetics, prenatal samples, cytogenetics, or biochemical genetics; most offer cytogenetic exams and specific PCR tests for few disorders, such as Fragile X mental retardation and cystic fibrosis. Most large laboratories perform molecular testing for infectious diseases, such as hepatitis, HIV, CMV, parvovirus, toxoplasmosis, and many others. Many large general laboratories are now offering genetic tests; some are done in house, while others are actually performed in other more specialized laboratories. Tests performed vary from the basic clinical genetics (chromosomes, FISH microdeletions, newborn screening, prenatal cytogenetics, molecular investigation) to more sophisticated exams such as array-CGH, linkage studies, sequencing. Specific tests for rare disease are quite often sent abroad, mostly to the USA, although such information is not easy to obtain from the laboratories. Just like the public services, the private laboratories are concentrated in the South-Southeast regions (more than $65 \%$ ). As there is hardly any control over tests offered, some even offer tests with questionable application, such genetic predisposition testing.

Newborn screening within the private sector is performed by six laboratories, who receive samples from many other private laboratories, who offer such testing in their menus. These laboratories screen as a whole around 250,000 babies per year, with tests varying among the most basic (like the national program) to the most sophisticated, including tandem mass spectrometry (available presently in only one private laboratory in Brazil).

According to the procedures listed in DATASUS, 249,980 amino acid chromatography, 2,427 organic acid analyses, 5,788 long duration culture karyotypes, 7,932 karyotypes in bone marrow samples or chorionic villi, 11,605 blood karyotypes, and 712 molecular tests for haemoglobin diseases or 
cystic fibrosis (confirmation) were performed in the country during 2009 through the public health system. Most of the metabolic exams are performed as part of the newborn screening program. It must mentioned that probably more tests are performed within the public sector, but its funding is not directly related to the SUS, ${ }^{8}$ so they do not get accounted for in the consulted database. Other exams may be performed but, as they are not coded, ${ }^{9}$ will not be listed. Regarding the private sector, such numbers are even harder to estimate, since the specific data is not open for consultation.

The most commonly tested conditions are those included in the newborn screening program: phenylketonuria, congenital hypothyroidism, and hemoglobin disease; all tests of the national program are performed in 32 laboratories. Figures are around 3 million tests/year, with laboratories available in all states. Regarding clinical genetics specifically, the most commonly tested conditions are chromosomal abnormalities. This is the only genetic nonbiochemical exam present in the list of the SUS, allowing laboratories to bill the local governments for reimbursement. For the rest of the list, a separate survey would be necessary.

In the largest public clinical genetic services the most frequently tested conditions are probably chromosomal abnormalities, Fragile-X syndrome, and microdeletion syndromes such as Angelman, Prader-Willi, Williams, and velocardiofacial. Around $80 \%$ of the private laboratories that investigate genetic diseases perform cytogenetic analysis; $80 \%$ perform molecular investigation with PCR for one or more genetic diseases. FISH is available in $30 \%$ and sequencing in around $20 \%$.

Concerning a regulation for genetic testing, the Ministry of Health established in 2001 the Committee on Access and Use of the Human Genome, whose work resulted in a document published in 2003 (Brazil 2001a; CAGH 2003) with recommendations about genetic tests and the ethical use of genetic information in the country, which are (1) diagnostic genetic tests, predictive or not, performed in the context of research involving humans, are volunteer, after proper guidance, and always preceded by the signing of informed consent (except tests of public health programs, as neonatal screening, and those that aim to reduce personal risk to health or health of third parties); (2) tests that are performed with a medical purpose in order to diagnose and establish appropriate schemes of therapy and prevention should not be indicated before its sensitivity, specificity and efficacy have been scientifically substantiated; (3) it is forbidden to request genetic tests as a prerequisite for job admission, except as provided in specific legislation, or

\footnotetext{
${ }^{8}$ Some university and research institutions have a closed budged and do not charge the tests to the SUS.

${ }^{9}$ Codes in the SUS for molecular investigation, for example, are not available.
}

granting benefits, by any public or private institution, or that the personal genetic information is used in a discriminatory manner in such institutions; (4) it is prohibited to disclose genetic test results to any person other than the individual himself or his legal representative; (5) genetic testing, both diagnostic and predictive, can only be performed by medical request; and (6) an educational effort for health professionals, and for the population is highly recommended, in order to clarify the benefits and risks of information obtained from genetic tests. Unfortunately, many produced documents are not widely used or applied.

Guidelines and recommendations related with the medical practice in genetics are scarce in Brazil. Aiming to assist in medical decision making and thus optimize the care of patients, the Brazilian Medical Association and the Federal Council of Medicine in 1999 triggered a process with the specialty societies for the development of medical guidelines based on scientific evidence currently available. Since 2000, the Brazilian Society of Medical Genetics contributed with seven guidelines: Clinical Genetics Evaluation of the Newborn, Familial Cancer, Female Sterilization: Statement, Male Sterilization: Indications, Laboratory Tests for Diagnosis of Symptomatic Diseases, Turner Syndrome: Diagnosis and Treatment, and Predictive Testing (CFM/AMB 2011). In 2010, the Brazilian Society of Medical Genetics started working intensively in elaborating 40 new guidelines.

\section{Prevention of congenital and genetic disorders}

Regarding public health policies related to the prevention of birth defects and disabilities, salt is iodised, wheat and maize flours are fortified with folic acid (Brazil 2002b), rubella immunization is available for children, adolescents, and adults, with the national immunization program including specific awareness campaigns for women in reproductive age (Brazil 2011d). Furthermore, there are labels in alcoholic beverages and cigarettes informing about consumption risks during pregnancy. Contraceptives and family planning are available through the "Women's Health Program"; unfortunately, no genetic preconception clinics are available.

There are no upcoming policies related to prenatal diagnosis or PGD. Issues related to abortion have also been presented previously in this text: A social movement has been growing stronger and possibly in the near future the law will be revised. After a petition put forward in 2004 to the Supreme Court, it was understood that terminating a pregnancy due to anencephaly could no longer be considered a crime (Diario Oficial da União 2012). It is important to point out that other severe conditions were not included; anencephaly was chosen and put forward as a strategy to begin with a lethal condition with a rather straightforward and early diagnosis. However, the subject was put forward as a strategy to begin with a lethal condition. 
Cultural and social issues pertaining to medical genetic services in Brazil

Participation of the users and decision making regarding health care is not a tradition in Brazil. Physicians are still viewed as detaining all information regarding health, and for a long time, people got used to being told what to do in this area. This has obviously been changing in the last decades, especially with the spread of access to communication and internet. Informed decisions in health, however, are still a changing reality in the country, as this has to be supported by general education of the public, and Brazil is still way behind in education when compared to other countries.

On the other hand, the importance of medical genetics and its integration into public health and prevention is not understood by most physicians, health authorities, public officials, and policy makers. Nor is the specialty of medical genetics known by many, who believe genetics will always be linked to very rare disorders, research, laboratories, and high cost. Such beliefs are true not only for lay people but also for health professionals. Due to such facts, many patients/families are not referred to specialized services or only arrive in genetic services after recurrences, which could have been prevented.

National policies and legal frameworks

The Brazilian Ministry of Health published a decree in 2009, which proposes the creation of a "National Policy for Comprehensive Care in Clinical Genetics at SUS" (Política Nacional de Atenção Integral em Genética Clinica no SUS) (Brazil 2009a). The process that led to acknowledge the need to establish such a policy began in 2001 and was partly influenced by the announcement of the sequencing of the human genome. The ethical, political, legal, and administrative matters related to the access to human genetic material became an issue in most countries, and a national committee was created, the aforementioned Committee on Access and Use of the Human Genome (Brazil 2001a). Some of the conclusions highlighted that most Brazilian regions were hardly prepared for the clinical genetics practice, while the committee addressed issues relevant to genomic medicine. Thus, with basic problems of infrastructure and shortcomings in the area, the challenge was to establish a minimum organizational structure, from which strategic actions would be applied to ensure comprehensive care in genetics. These actions would have to provide a universal, fair and equitable access to tests and procedures, including genomic technology. ${ }^{10}$ However,

\footnotetext{
${ }^{10}$ Memory of the Committee on Access and Use of the Human Genome's 1st Meeting (August 2001), 2nd meeting (December 2001) and document presented by one of the authors of this chapter (Marques-de-Faria AP). Ministry of Health, Department of Health Policy, Department of Science and Technology in Health, 2001.
}

as such initiatives far transcended the initial attributions of the committee and depended on a specific action of Health Ministry, the process was postponed until a Working Group (WG) was formally established by an ordinance in 2004 to address the issue (Brazil 2004).

The WG had as designated task the development of the National Policy for Comprehensive care in Clinical Genetics at SUS, taking in consideration the lack of regulation and standardization, and also regional inequities in health care in clinical genetics in the country. The coordination of the WG was held by the Department of Science and Technology and by the Department of Healthcare (SAS) of the Ministry of Health. It was formed by representatives of various agencies and entities of the Ministry of Health, of the Brazilian Society of Medical Genetics (SBGM), of the Brazilian Society of Genetics (SBG), and of reference services in Clinical Genetics. During the period 2004-2006, aiming to assess the situation of care in clinical genetics and to promote a debate on the various instances of the SUS, involving local health care managers and service providers, as well as to obtain grants for the development of the policy, there were several meetings and two regional workshops (South/ Southeast and North/Northeast/Center-West). Representatives of the Ministry of Health also participated in inserts during clinical genetic conferences.

This process resulted in a proposal that ultimately led to the ordinance No. 81 of the Ministry of Health in January 20th 2009, which established the National Policy for Comprehensive care in Clinical Genetics within the SUS (Brazil 2009a), and also designated the strategies for actions that must be taken into account in its regulation. This was a long overdue landmark for medical genetics professionals in Brazil. Care networks would be established based on the actions of the Health Secretariats together with the multiple Municipal Health Secretariats. The agreement between the state and municipal managers from each region would determine the organization and would also provide the necessary conditions for the networks' operation. Such organization would have to follow specific guidelines proposed by the Ministry of Health; the ministry would also support the network organization by partially financing the system (CONASS 2007).

The implementation of such policy would be progressive, taking into account local capacities of network organization. The major structuring axis for health care in clinical genetics would be Genetic Counseling, which must be guaranteed to any individual or family who may require it. Care guidelines should be established for investigating the most frequent conditions such as mental retardation, congenital anomalies, and inborn errors of metabolism. A thorough evaluation of the financial impact of the inclusion of specific genetic tests and of genetic counseling in health costs/financing is still needed. In addition, manuals and guidelines should be developed to guide professionals from Primary and Specialized 
Care. All these initiatives and other necessary measures for fully structuring, monitoring and improving the policy would be empowered to the SAS, who would pursue these actions through the constitution of a technical advisory board (CONASS 2007).

The existence of a published policy for genetics is an important historical fact. By the time this text was written, however, no supplementary ordinance, which would be absolutely essential to organize and regulate this policy, had been published. At least, supported by the epidemiological transition, the need for an organized action in the area of medical genetics/birth defects in Brazil has been acknowledged. Since January 2009, the Brazilian Genetic Alliance, several patient-parent organizations and the SBGM have been trying to push the Ministry of Health for the implementation of this special policy.

\section{Research priorities in genetics/genomics}

Brazil has made significant investments to fund research in medical genetics and genomics. The main funder is the public sector, both state and federal. At the federal level, the major funders are the Financier of Studies and Projects [Financiadora de Estudos e Projetos (FINEP)], the Coordination of Improvement of Higher Education Personnel [Coordenação de Aperfeiçoamento de Pessoal de Nivel Superior (CAPES)], and the National Council for Scientific and Technological Development [Conselho Nacional de Desenvolvimento Cientifico e Tecnológico (CNPq)]. FINEP is undertaking under the Ministry of Science and Technology (MCT), which focuses on fostering the institutional projects (universities, companies, and institutes of technology). CAPES invests in training high-level human resources in the country and abroad.

The CNPq is an agency of the MCT for the promotion of scientific and technological research and training of human resources for research in the country. It focuses on encouraging researchers and their projects, individually or in groups. $\mathrm{CNPq}$, in particular, has supported specific actions in Clinical Genetics through partnerships with the Ministry of Health. The 2006 and 2010 edicts have common points as the aim to support structuring projects for health care in Medical Genetics throughout the country (CNPq 2006; CNPq 2010). Among the projects approved in the edict of 2006, several were structured partnerships with institutions in several states of Brazil, forming various networks such as Familial Cancer Network, the Network for Diagnosis in Inborn Errors of Metabolism (Rede-EIM-Brasil), and others. FINEP acts at the federal level, a public company linked to the MCT.

At the state level there are Foundations for Research Support [Fundação de Amparo a Pesquisa (FAP)] in each state of Brazil. One of these FAPs, the Foundation for
Research Support of São Paulo (FAPESP), is the fourth largest funder of scientific and technological development of the country. In 2009 FAPESP grant aid totaled nearly $\$ 500$ million for various areas of knowledge. A major achievement of this entity was the establishment of genomic research in the country, from an agreement set with the ONSA network (Organization for Nucleotide Sequencing and Analysis) in 1997 (Simpson and Perez 1998). These efforts resulted in the sequencing of the genome of Xylella fastidiosa in 2000 (Simpson et al. 2000) and established an expert network on advanced projects in genomics, with international impact, whose most important product in human genetics was the Human Cancer Genome Project (2011). In this bold project, about 2 million DNA sequences of normal and tumor tissue were deposited in GENBANK (Brentani et al. 2003) and derivated other projects as the Clinical Genome Cancer Project (Wünsch-Filho et al. 2006).

Another form of support is the partnership of different funders (CNPq, CAPES, FAP, Ministry of Health, Ministry of Education, and others) by financing bold projects, like the program National Institutes of Science and Technology (Institutos Nacionais de Ciencia e Tecnologia (INCT) 2011). Released in July 2008, this program has established itself as a powerful instrument for advancing science, technology, and innovation in the country. With over a hundred projects approved in different research areas, such as health, biotechnology, nanotechnology, and energy, the program aims to mobilize and aggregate in networks the best research groups in frontier areas of science and in strategic areas for the sustainable development of the country. Some of the institutes are created directly or indirectly linked to the development in Human Genetics and Medicine: National Institute of Science and Technology Cell Therapy, based in the Faculty of Medicine of Ribeirão Preto University of São Paulo; National Institute of Science and Technology of Stem Cells in Human Genetic Diseases, based at the Institute of Biosciences, University of São Paulo; National Institute of Science and Technology for Cancer Control, based at the National Cancer Institute (linked to the Ministry of Health); National Institute of Population Medical Genetics, based at the Hospital de Clinicas de Porto Alegre-Federal University of Rio Grande do Sul (INAGEMP 2011); National Institute of Science and Technology of Molecular Medicine, based at the Faculty of Medicine, Federal University of Minas Gerais; and the National Institute of Science and Technology in Oncogenomics, based at the Cancer Hospital of São Paulo.

\section{Patient organisations and public education in genetics}

It is very hard to access data on how many organizations for genetic disorders exist in Brazil. Data provided by the 
Aliança Brasileira de Genetica (the Brazilian branch of the Genetic Alliance) counts there are 40 affiliated organizations. But this is certainly underestimated, as the Brazilian Federation of Down's Syndrome Associations alone, which congregates over 60 associations of Down's syndrome plus other organizations who fight for inclusion of handicapped people in the society, are not part of the Alliance. A rough estimate would be at least 100 different organizations, some just plain "kitchen table" and very few more professionally organized, such as the cystic fibrosis (CF) group that congregates 21 state $\mathrm{CF}$ associations and was responsible for the national newborn screening program in Brazil.

As stated above, the structure of such organizations vary widely, although most operate on a voluntary basis, do not have a physical structure or the resources to hire employees, being helped by its members when necessary and on demand. Most are financed by donations of their own board of directors and members; support from the society in general is quite rare, or is there official information regarding financing of these organizations. Their activities comprise educating health professionals and the society in general about specific genetic diseases, some are involved with advocating for public policies and few provide care for patients. Advocacy actions comprise inclusion in society and for education, awareness regarding rare diseases and funding for research and lobbying for the approval of policies for research and treatment for rare diseases. The majority are somehow linked to a university, research/reference diagnostic or treatment centre for genetic disorders.

Contrary to several countries, where people give their time, working as volunteers, and donate money, this is still not the rule in Brazil. A simplistic form of interpreting it would be stating that Brazil is a poor country. But this is hardly the main reason; the reason is mostly cultural. Some people not used to giving, they expect to receive, especially from the government. Sometimes, not giving also is a sign of lack of trust, trust that all the donated money will actually be used in the right way.

Groups such as the Genetic Alliance and many of the patient-parent organizations have matured over the years around the world as acts of citizenship. The same cannot be said about Brazil, where people are just beginning to understand they can and must speak up. The country is still awaking from years of dictatorship. It is also hard to have participation among poor and uneducated people, unfortunately still a reality in the country. Support groups have been growing in Brazil, but most are still very amateur.

\section{Conclusion}

Care in medical genetics does not necessarily involve high costs and high technology. Health actions do not differ conceptually from other health care actions,and involve the various aspects of diagnosis, prevention, and treatment. That way, organizing a network in Brazil would be nothing more than properly channeling the investments, and structuring the already existing services in an integrated and efficient manner, leading to a fair and more democratic access to health care.

In addition to formalizing and carrying out the organization of a network in clinical genetics in Brazil, other actions need to be implemented for the system not only to properly function but also to be gradually expanded and adapted to the country's growing needs. Government initiatives that already exist should be consolidated, and non-governmental programs may eventually be added and enrich the system. As examples of optimization and integration, informing city officials about the importance of the correct completion of the fields regarding birth defects in the newborn declarations should be encouraged. Such data will be of great relevance for monitoring incidences of birth defects, programming specific health actions and evaluating the effectiveness of actions already implemented, such as folic acid fortification in flour. The importance of patient-parent organizations should also be reinforced; besides offering support and comfort to their members, such associations have as goal the dissemination of information among lay people and also to physicians. These non-governmental associations can also play the fundamental role of introducing new topics on the political agenda.

Finally, the issue of prevention must be addressed. We could have pages of discussion on what is acceptable and what would be considered ethical; for many situations in genetics, early detection (in some cases, during pregnancy) is the only way to prevent the birth of an affected child. It is important to note that professionals, geneticists or not, are often faced with issues of great ethical and legal complexity. In such instances, education is crucial. Complex decisions should only be made based on real understanding, as well as respecting people's rights, and families should have autonomy in their decisions.

The network configuration of services in clinical genetics engaging municipal, state, and federal levels-regionalized, hierarchical, and functional, as recommended in the creation of the SUS - will be a crucial item for the care in medical genetics. Considering the magnitude of the impact that birth defects and genetic diseases already have on health, even in a country like Brazil, as well as all the perspectives generated by the advances in this field, it must be assured that genetic services and testing are truly and ethically integrated into health care in Brazil and become part of the Unified Health System.

Acknowledgement The survey was supported by the following: (1) The "Institute for Health and Consumer Protection" (Italy), one of the seven scientific institutes of the Joint Research Centre (JRC) of the 
European Commission; (2) The Department of Human Genetics, Hannover Medical School, Hannover, Germany; and (3) The Unit of Women's Health Research, Medical School, Westfaelische WilhelmsUniversitaet Muenster, Muenster, Germany.

Conflict of interest statement The authors declare that they have no conflict of interest

\section{References}

Brazil (1990a) Lei no. 8069 de 13 de julho de 1990. Dispõe sobre o estatuto da criança e do adolescente e dá outras providências. Inciso III, artigo 10. Diário Oficial da União Jul 16; p.13563

Brazil (1990b) Presidência da República. Lei no. 8.080 de 19 de setembro de 1990. Dispõe sobre as condições para a promoção, proteção e recuperação da saúde, a organização e o funcionamento dos serviços correspondentes e dá outras providências

Brazil (1992) Ministério da Saúde, Gabinete do Ministro. Portaria GM/ MS no. 22, 199215 Jan. Trata do programa de diagnóstico precoce do Hipotireoidismo Congênito e Fenilcetonúria

Brazil (2001b) Ministério da Saúde, Gabinete do Ministro. Portaria GM/ MS no. 822, 200106 Jun. Institui, no âmbito do Sistema Único de Saúde, o Programa Nacional de Triagem Neonatal/PNTN

Brazil (2001c) Ministério da Saúde, Secretaria de Assistência à Saúde. Portaria SAS no. 189, 200106 Jun. Institui, no âmbito da Secretaria de Assistência à Saúde - Ministério da Saúde, o Grupo Técnico de Assessoramento em Triagem Neonatal

Brazil (2001d) Programa Fibrose Cística http://dtr2001.saude.gov.br/ sas/PORTARIAS/Port2001/PT-263.htm - Portaria SAS/No. 263 de 18 de julho de 2001 - Aprova o PROTOCOLO CLÍNICO E DIRETRIZES TERAPÊUTICAS - FIBROSE CÍSTICA - Enzimas Pancreáticas

Brazil (2001e) Ministério da Saúde, Gabinete do Ministro. Portaria GM/MS no. 2305, 2001 Dez 19. Aprova o Protocolo de Indicação de Tratamento Clínico da osteogenesis imperfecta com pamidronato dissódico no âmbito do Sistema Único de Saúde - SUS

Brazil (2002a) Ministério da Saúde, Secretaria de Assistência à Saúde. Portaria SAS no. 449, Jul 08. Aprova o protocolo clínico e diretrizes terapêuticas - doença de Gaucher-Imiglucerase. Diário Oficial da União Jul 09; 130(1)

Brazil (2002b) Agência Nacional de Vigilância Sanitária. Resolução - RDC no. 344, de 13 de dezembro de 2002. Aprova o Regulamento Técnico para a Fortificação das Farinhas de Trigo e das Farinhas de Milho com Ferro e Ácido Fólico. Diário Oficial da União, Brasília, DF, 18 dez

Brazil (2006) Ministério da Saúde-Instituto Nacional do Câncer: Situação do câncer no Brasil. Available at: http://iah.iec.pa.gov.br/iah/fulltext/ $\mathrm{pc} /$ monografias $/ \mathrm{ms} /$ situcancerbrasil/situcancerbras2006.pdf

Brazil (2008) Ministério da Saúde. Abortion and Public Health: 20 years (20 anos de pesquisas sobre aborto no Brasil). Available at: http://bvsms.saude.gov.br/bvs/publicacoes/livreto.pdf

Brazil (2009a) Ministério da Saúde, portaria GM no. 81, 20 de janeiro de 2009-Institui, no ambito do Sistema Único de Saude (SUS), a Politica Nacional de Atenção Integral em Genetica Clinica. Diário Oficial da União 21/01/2009

Brazil (2009b) Ministério da Saúde. SINASC (Sistema de Informações sobre nascidos vivos), data regarding the year of 2006. Available at: http://tabnet.datasus.gov.br/cgi/tabcgi.exe?sinasc/cnv/nvuf.def

Brazil (2009c) Ministério da Saúde, Departamento de Informação e Informática do SUS - DATASUS, Sistema de Informações de Saúde. Sistema de Informações Hospitalares-SIH/SUS. http:// tabnet.datasus.gov.br/cgi/tabcgi.exe?sih/cnv/nruf.def

Brazil (2009d) Ministério da Saúde. Instituto Nacional do Câncer. Rede nacional de câncer familial: manual operacional/Instituto Nacional de Câncer - Rio de Janeiro: INCA, 2009. 229p
Brazil (2010) Ministério da Saúde, Departamento de Informação e Informática do SUS-DATASUS, Sistema de Informações de Saúde. Mortalidade infantil (menores de um ano). http://tabnet. datasus.gov.br/cgi/deftohtm.exe?sim/cnv/obt10uf.def

Brazil (2011a) DATASUS - Health Information Database. Ministério da Saúde-Departamento de Informática do SUS. http:// www2.datasus.gov.br/DATASUS/index.php

Brazil (2011b) Regulatory bodies. National Agency of Supplementary Health (ANS). http://www.brasil.gov.br/sobre/brazil/structure/ 1 regulatory-bodies/br_model1?set_language $=$ en

Brazil (2011c) LEI No. 12.470, DE 31 DE AGOSTO DE 2011-DOU DE 1/09/2011-dispõe sobre o Plano de Custeio da Previdência Social e outros

Brazil (2011d) Information on the National Immunization Program in Brazil. http://portal.saude.gov.br/portal/saude/profissional/visualizar_ texto.cfm?idtxt=29489

Brasil, Ministério da Saúde (1999) Sistema de Informações sobre nascidos vivos. Manual de instruções para o preenchimento da declaração de nascido vivo, 3ed

Brasil, Ministério da Saúde (2001a) Portaria No. 470/GM, de 6 de abril de 2001-Institui a comissão sobre acesso e uso do genoma humano

Brasil, Ministério da Saúde (2004) Portaria GM no. 2.380, de 28 de outubro de 2004-Institui o Grupo de Trabalho de Genética Clínica, e dá outras providências. Diário Oficial da União, 209 (Oct 29, 2004)

Brentani H, Caballero OL, Camargo AA, da Silva AM et al (2003) The generation and utilization of a cancer-oriented representation of the human transcriptome by using expressed sequence tags. Proc Natl Acad Sci USA 100:13418-13423

Brunoni D (1997) Estado atual do desenvolvimento dos serviços de genética médica no Brasil. Braz J Genet 20:11-23, suppl

Brunoni D (2002) Aconselhamento genético. Ciência Saúde Coletiva 7 (1):101-107

CAGH (2003) Comissão sobre Acesso e uso do Genoma HumanoInformação genética- Testes genéticos e recomendações (2003). Ministério da Saúde, Secretaria de Ciência, Tecnologia e Insumos Estratégicos. Departamento de Ciência e Tecnologia. Available at: http://www.ghente.org/temas/informacao/testes_geneticos.pdf

Castilla EE, Orioli IM (2004) ECLAMC: The Latin-American Collaborative Study of Congenital Malformations. Community Genet 7:76-94

Castilla EE, Lopez-Camelo JS, Paz JE, Orioli IM (1996) Introducción. In: Dutra MG (ed) Prevención primaria de los defectos congénitos. Editora Fiocruz, Rio de Janeiro, pp 11-17, organizador

CFM (2011a) Conselho Federal de Medicina. Observatório do SUS. http://portal.cfm.org.br/index.php?option $=$ com content\&view $=$ article\&id $=21887$ :observatorio-do-sus\&catid $=3$

CFM (2011b) Conselho Federal de Medicina. Informações sobre saúde suplementar no Brasil. http://portal.cfm.org.br/index.php? option $=$ com_content $\&$ view $=$ article $\& i d=22200$ : informacoessobre-a-saude-suplementar-no-brasil\&catid=3

CFM/AMB - Conselho Federal de Medicina e Associação Medica Brasileira (2011) Projeto Diretrizes: http://www.projetodiretrizes.org.br/ novas_diretrizes_sociedades.php

Christianson A, Howson CP, Modell B (2006) March of Dimes Global Report on Birth Defects. New York. March of Dimes Birth Defects Foundation. Available online at: http://www.marchofdimes.com/downloads/Birth_Defects_Report-PF.pdf and http:// www.marchofdimes.com/downloads/BirthdefectsAppendixB.pdf

CNPq (2006) MCT/CNPq/MS-SCTIE-DECIT 21/2006 edict (http:// portal.saude.gov.br/portal/files/pdf/genetica.pdf) - text available in Portuguese from the author

CNPq (2010) MCT/CNPq/CT-HEALTH No. 57/2010 edict (http:// www.cnpq.br/editais/ct/2010/057.htm) 
Cunha J, Aerts D, Leite JCL1, Castilla EE (2002) Defeitos congênitos em Porto Alegre: uma investigação da qualidade dos dados registrados na Declaração de Nascido Vivo. Revista Brasileira de Epidemiologia (supl.)51.

Secretaria de Educação Superior-Comissão Nacional de Residência Medica-Ministério da Educação (2009) Sistema CNRM-Instituição x Programas x Vagas-Programas de Residência em Genética Médica. http://mecsrv04.mec.gov.br/sesu/ SIST_CNRM/APPS/inst_especialidades.asp

Dal Pizzol T, Sanseverino MT, Mengue SS (2008) Exposure to misoprostol and hormones during pregnancy and risk of congenital anomalies. Cad Saúde Pública Rio de Janeiro 24(6):1447-1453

Sociedade Brasileira de Genética (2009a) Histórico. http://www.sbg.org.br/ AtaFundacao.html

Sociedade Brasileira de Genetica (2009b) Relação dos Aprovados em Concurso de Título de Especialista. http://www.sbg.org.br/ relPremioTitEspecialista.html

Instituto Nacional de Genética Medica Populacional (INAGEMP) (2011) http://www.inagemp.bio.br/overview

Comissão Nacional de Residência Medica (2006) Resolução CNRM no. 02 , de 15 de maio de 2006. Dispõe sobre requisitos mínimos dos Programas de Residência Médica e dá outras providências. http://portal.mec.gov.br/sesu/arquivos/pdf/cnrm/resolcnrm002 2006.pdf

CONASS (Conselho Nacional de Secretários de Saúde) (2007) Política Nacional de Atenção Integral em Genética Clínica. Nota Técnica n. ${ }^{\circ} 05 / 2007$. http://www.conass.org.br/admin/arquivos/NT05-07.pdf

Diario Oficial da União - seção 1, 17/04/2003-Lei no. 10.651, de 16 de abril de 2003. Dispõe sobre o controle do uso da talidomida. Available at: http://www.in.gov.br/imprensa/visualiza/index.jsp? jornal $=1 \&$ pagina $=1 \&$ data $=17 / 04 / 2003$

Diário Oficial da União - seção 1, 24/03/2011—Agência Nacional de Vigilância Sanitária-Resolução-RDC, de 22 de março de 2011. Dispõe sobre o controle da substância Talidomida e do medicamento que a contenha. Available at: http://www.in.gov.br/imprensa/ visualiza/index.jsp?.jornal $=1$ \&pagina $=82 \&$ data $=24 / 03 / 2011$

Diario Oficial da União - seção 1, 24/04/2012 - Decisão: Arguição de Descumprimento de Preceito Fundamental 54 (ADPF 67115 Supremo Tribunal Federal). Available at: http://www.in.gov.br/ imprensa/visualiza/index.jsp?.jornal $=1 \&$ pagina $=1 \&$ data $=24 / 04 /$ 2012

Diniz D, Medeiros M (2010) Abortion in Brazil: a household survey using the ballot box technique. Ciência Saúde Coletiva 15(Supl. 1):959-966

Genetica Clinica (2009) Discussion list. Managed by Dr. Victor Evangelista de Faria Ferraz, Departamento de Genética da Faculdade de Medicina de Ribeirão Preto, Universidade de São Paulo, Brasil. http:/health. groups.yahoo.com/group/geneticaclinica

Freire-Maia N (1981) The extraordinary handless and footless families of Brazil - 50 years of acheiropodia. Am J Med Genet 9:31-41

Freire-Maia N, Cavalli IJ (1980) Albinism, skin carcinoma and chromosome aberrations. Clin Genet 17:46-47

Giugliani R (2010) Inborn errors of metabolism in Latin America: challenges and opportunities. J Inherit Metab Dis 33(Suppl 2): S315-S320

Guerra FA, Llerena JC Jr, Gama SGN, Cunha CB, Theme Filha MM (2008a) Defeitos congênitos no Município do Rio de Janeiro, Brasil: uma avaliação através do SINASC (2000-2004). Cad Saúde Pública, Rio de Janeiro 24(1):140-149

Guerra FA, Llerena JC Jr, Gama SGN, Cunha CB, Theme Filha MM (2008b) Confiabilidade das informações das declarações de nascido vivo com registro de defeitos congênitos no Município do Rio de Janeiro, Brasil, 2004. Cad Saúde Pública, Rio de Janeiro 24(2):438-446

Horovitz DDG (2003) Atenção aos defeitos congênitos no Brasil: propostas para estruturação e integração da abordagem no sistema de saúde [Tese de Doutorado]. Instituto de Medicina Social, Universidade do Estado do Rio de Janeiro, Rio de Janeiro

Horovitz DDG, Llerena JC Jr, Mattos RA (2005) Atenção aos defeitos congênitos no Brasil: panorama atual. Cad Saude Publica 21 (4):1055-1064

Human Cancer Genome Project (2011) http://www.ludwig.org.br and http://www.licr.org

IBGE (1999) Infant mortality in Brazil-historical series. Mortalidade infantil—serie histórica-doc IBGE 1999-Ministério do Planejamento, Orçamento e Gestão-Instituto Brasileiro de Geografia e Estatística (IBGE)-Diretoria de Pesquisas, Departamento de População e Indicadores Sociais. Estudos e Pesquisas-Informação Demográfica e Socioeconômicanúmero 2-Evolução e Perspectivas da Mortalidade Infantil no Brasil, Rio de Janeiro

IBGE (2009) Fundação Instituto Brasileiro de Geografia e Estatística. Estatísticas da saúde: assistência médico-sanitária 2009. Rio de Janeiro; 2010 Available at: www.ibge.gov.br/home/estatistica/ populacao/condicaodevida/ams/2009/ams2009.pdf

IBGE (2010) Fundação Instituto Brasileiro de Geografia e Estatística; Brasil em Síntese. http://www.ibge.gov.br/brasil em sintese/ default.htm

IBGE (2011) Fundação Instituto Brasileiro de Geografia e EstatísticaSinopse do Censo Demográfico 2010. Rio de Janeiro, 2011. Available at: http://www.ibge.gov.br/home/estatistica/populacao/ censo2010/sinopse.pdf

CEInfo - Coordenação de Epidemiologia e Informação (2011) Manual de preenchimento da Declaração de Nascido Vivo. São Paulo: Secretaria Municipal da Saúde São Paulo (cidade). Declaração de Nascido Vivo. 24p

Macedo-Souza LI, Kok F, Santos S, Amorim SC, Starling A, Nishimura A, Lezirovitz K, Lino AMM, Zatz M (2005) Spastic paraplegia, optic atrophy, and neuropathy is linked to chromosome 11q13. Ann Neurol 57:730-737

Macedo-Souza LI, Kok F, Santos S, Licinio L, Lezirovitz K, Cavacana N, Bueno C, Amorim S, Pessoa A, Graciani Z, Ferreria A, Prazeres A, Nogueira de Melo A, Otto PA, Zatz M (2009) Spastic paraplegia, optic atrophy, and neuropathy: new observations, locus refinement, and exclusion of candidate genes. Ann Hum Genet 73:382-387, PubMed: 19344448

Marques-de-Faria AP (2006) Case study 1: Newborn Screening in Brazil. In: Medical Genetics Services in Developing Countries: The Ethical, Legal and Social Implications of Genetic Testing and Screening. World Health Organization. WHO Human Genetics Publications. Available at: http://www.who.int/genomics/ publications/GTS-MedicalGeneticServices-oct06.pdf

Marques-de-Faria AP, Ferraz VFE, Acosta AX, Brunoni D (2004) Clinical genetics in developing countries: the case of Brazil. Community Genet 7:95-105

Monlleo IL, Gil-da-Silva-Lopes VL (2006) Craniofacial anomalies: description and evaluation of treatment under the Brazilian Unified Health System. Cad Saude Publica 22:913922

PNTN_-Programa Nacional de Triagem Neonatal-relatório (2007) (National Newborn Screening Program-2007 report). Available at: http://portal.saude.gov.br/portal/arquivos/pdf/INDICADORES TRIAGEM NEONATAL.pdf

Porciuncula CGG (2004) Avaliação do Ensino de Genética Médica nos Cursos de Medicina no Brasil. Tese (Doutorado em Ciências Médicas). Faculdade de Ciências Médicas, Universidade de Campinas, Campinas

Quelce-Salgado A (1964) A new type of dwarfism with various bone aplasias and hypoplasias of the extremities. Acta Genet Stat Med $14: 63-66$

Schüller-Faccini L, Schvartzman L, Cecchin C (2001) Teratogênese humana e o SIAT. In: Sanseverino MT, Spritzer D, Schüller- 
Faccini L (organizadores). Manual de teratogênese. Porto Alegre: Editora da Universidade, p. 11-7

Senado Federal (1988) Constituição da Republica Federativa do Brasil, Imprensa Oficial do Estado S.A. IMESP

SIAT (2011) Serviço de Informação Sobre Agentes Teratogênicos. http:/gravidez-segura.org/

Simpson AJ, Perez JF (1998) ONSA, the São Paulo Virtual Genomics Institute. Organization for Nucleotide Sequencing and Analysis. Nat Biotechnol 16:795-796

Simpson AJG, Reinach FC, Arruda P, Abreu FA et al (2000) The genome sequence of the plant pathogen Xylella fastidiosa. Nature 406:151-157

Statute of the Child and Adolescent (1990) http://www.eca.org.br/ ecai.htm

Institutos Nacionais de Ciencia e Tecnologia (INCT) (2011) http:// www.cnpq.br/programas/inct/_apresentacao/docs/livro.pdf
UNDP (2009) International Human Development Indicators-United Nations. Available at: http://hdrstats.undp.org/en/countries/ profiles/BRA.html

United Nations (2010) Demographics and Social Statistics/Brazil. http://data.un.org/CountryProfile.aspx?crname $=$ Brazil

WHO (2000) World Health Organization, Human Genetics Programme (2000). Primary health care approaches for prevention and control of congenital disorders and disability. Report of a WHO meeting. World Health Organization WHO/HGN/WG/00.1

WHO (2010) World Health Organization (2010). World Health Statistics 2010. Available at: www.who.int/whosis/whostat/ EN WHS10 Full.pdf

Wünsch-Filho V, Eluf-Neto J, Lotufo PA, da Silva Jr WA, Zago MA (2006) Epidemiological studies in the information and genomics era: experience of the Clinical Genome of Cancer Project in São Paulo, Brazil. Braz J Med Biol Res 39:545-553 